\title{
City Branding Sawahlunto Kota Wisata Tambang Yang Berbudaya Melalui Event Sawahlunto International Songket Carnival (Sisca) 2016
}

\author{
Nurkhalila Fajrini ${ }^{1}$, Iriana Bakti ${ }^{2}$, dan Evi Novianti ${ }^{3}$ \\ ${ }_{1,2,3}$ Universitas Padjadjaran
}

\begin{abstract}
ABSTRAK
Songket Silungkang merupakan produk andalan hasil kerajinan masyarakat kota Sawahlunto. Sejarah songket dan sejarah tambang memperkuat city branding Sawahlunto dalam mewujudkan visi "Kota Wisata Tambang Yang Berbudaya" yang tertuang dalam Peraturan Daerah No. 2 Tahun 2001 pada event SISCa. Pada SISCa 2016, transformasi Kota Wisata Tambang Yang Berbudaya direalisasikan melalui konsep dan desain penampilan peserta karnaval. Penelitian ini bertujuan untuk mengetahui alasan dan latar belakang penyelenggara menjadikan Sawahlunto International Songket Carnival (SISCa) 2016 dalam city branding Sawahlunto Kota Wisata Tambang yang Berbudaya, pemahaman penyelenggara terkait SISCa 2016 dan tindakan komunikasi yang dilakukan penyelenggara SISCa 2016 dalam rangka city branding Sawahlunto. Metode yang digunakan dalam penelitian ini adalah metode kualitatif dengan jenis penelitian studi kasus. Teori konstruksi sosial atas realitas dan konsep city branding menjadi landasan dalam membahas hasil penelitian. Hasil penelitian menunjukkan bahwa alasan penyelenggara menjadikan SISCa 2016 dalam city branding Sawahlunto adalah adanya keterkaitan dampak yang ditimbulkan dari SISCa 2016 tersebut yakni, dampak ekonomi dan dampak pariwisata. Pemahaman penyelenggara SISCa 2016 terkait city branding kota Sawahlunto tertuang dalam Misi SISCa 2016 sebagai bentuk transformasi visi kota dengan mengangkat konsep wisata tambang. Tindakan komunikasi yang dilakukan penyelenggara melalui tiga tahapan komunikasi, yakni (1) komunikasi tahap awal SISCa antara pemerintah dengan pihak internal dan eksternal, (2) komunikasi saat berlangsungnya SISCa 2016 secara verbal dan non verbal, dan (3) komunikasi pasca SISCa 2016 dilakukan untuk menjalin hubungan baik dalam persiapan SISCa selanjutnya. Dengan demikian, penyelenggaraan SISCa 2016 dianggap sebagai salah satu bentuk promosi daerah sebagai perwujudan visi kota Sawahlunto.
\end{abstract}

Kata-kata Kunci: Sawahlunto international songket carnival (sisca) 2016; city branding; kota sawahlunto; kota wisata tambang yang berbudaya; event

\section{City Branding Sawahlunto "The Cultured Coal Mining Tourism City” Through The Sawahlunto International Songket Carnival Event (Sisca) 2016}

\section{ABSTRACT}

Songket Silungkang is the featured product of handicrafts community in Sawahlunto. The Songket History and The Mining Coal History added city branding concept of Sawahlunto in realizing the vision of the city "The Cultured Coal Mining Tourism City" that has been contained in the Local Regulation No. 2 since 2001 on the SISCa event. In SISCa 2016, the transformation of The Cultured Coal Mining Tourism City is realized through the concept and design of the appearance of carnival participants. This research is purposed to know the reasons and background of the organizers to held Sawahlunto International Songket Carnival (SISCa) 2016 in city branding Sawahlunto as The Cultured Coal Mining Tourism City, to know understanding organizers associated SISCa 2016 and communication actions of organizers in SISCa 2016 within the framework of city branding Sawahlunto. The method used in this research is qualitative method with case study. The theory of the social construction of reality and city branding concepts are the basis framework for discussing the results of the study. The result of this research shows that the reason of the organizers to held SISCa 2016 for Sawahlunto city branding is the relationship of impact from the SISCa 2016, namely, the economic impact and the tourism impact. The understanding organizers of SISCa 2016 related with Sawahlunto city branding is stated from Mission SISCa 2016 as a form of transformation city vision by lifting the coal mining tourism concept. Communication actions has been done by organizers through three stages of communication, namely (1) the communication in the beginning stage of SISCa 2016 between governments with internal and external parties, (2) communication in during of SISCa 2016, namely, verbal and non-verbal communication, and (3) communication post of SISCa 2016 carried out for establish a good relationship in preparation for the next SISCa. Thus, the implementation of SISCa 2016 has been considered as a form of the region promotion through songket carnival as realized of the vision of Sawahlunto.

Keywords: Sawahlunto international songket carnival (sisca) 2016; city branding; sawahlunto city; the cultured coal mining tourism city; event

Korespondensi: Nurkhalila Fajrini, S.I.Kom., M.I.Kom. Universitas Padjadjaran. Kampus Jatinangor, J1. Raya Bandung Sumedang Km. 21, Jawa Barat 45363. Email: ellakhalila.nf@gmail.com 


\section{PENDAHULUAN}

Songket merupakan salah satu produk unggulan dari kota Sawahlunto, yang dikenal dengan songket Silungkang. Nama songket Silungkang, sesuai dengan nama daerah penghasilnya, yaitu Silungkang. Silungkang merupakan salah satu daerah di kota Sawahlunto yang telah lama menghasilkan kain tenun songket. Kata songket berasal dari sungkit yaitu cara menambah benang pakan dan benang emas pada benang lungsi. Pembuatan songket ini telah menjadi mata pencaharian masyarakat lokal.

Songket merupakan produk tekstil yang telah dikenal sebagai warisan budaya. Songket dikenal bukan hanya karena keindahan kilau benang emas dalam berbagai motif yang unik saja, melainkan juga karena fungsi sosialnya sebagai alat kelengkapan kostum tradisional. Terkait keberhasilan produksi songket Silungkang tersebut, songket Silungkang dikenal sebagai sebuah produk peradaban bernilai tinggi yang diminati oleh banyak wisatawan dan telah menjadi salah satu sumber ekonomi masyarakat dan pariwisata Sawahlunto.

Pada tahun 2015, pemerintah Sawahlunto menggelar kegiatan dalam rangka meningkatkan promosi songket Silungkang, yang dikenal dengan Sawahlunto International Songket Carnival (yang selanjutnya disingkat SISCa).
Kegiatan SISCa di tahun 2015 digelar pada tanggal 28-30 Agustus. Setelah melakukan pembangunan Kompleks Pasar Songket di dekat area Kantor Camat Silungkang pada awal 2015, SISCa 2015 telah dapat menguatkan pasar produk songket secara keseluruhan, selain itu juga dapat mendukung pembangunan pariwisata kota Sawahlunto. Pada SISCa 2015 melibatkan sekitar 1500 peserta berpakaian tenun songket Silungkang dalam mengisi Sawahlunto sebagai Kota Warisan Nasional. Berkat kegiatan tersebut, Sawahlunto mendapatkan penghargaan dari Museum Rekor Indonesia (Muri) dengan mencatat 17.290 warga yang menggunakan songket pada hari tersebut.

Keberhasilan yang dicapai dalam event tersebut menjadikan SISCa sebagai kegiatan tahunan yang diselenggarakan di kota Sawahlunto. Pada tahun 2016, pemerintah kembali mengadakan SISCa yang diselenggarakan pada 25-27 Agustus. Beberapa ketentuan yang disyaratkan oleh panitia dalam lomba dan karnaval tersebut adalah kreasi harus mempunyai komposisi bahan minimal $80 \%$ songket dan $20 \%$ bahan campuran.

Terkait dengan konsep tambang kota Sawahlunto, berbagai desain songket dari seluruh peserta terlihat menunjukkan bentukbentuk atraksi tambang batubara. Desain tambang yang ditampilkan oleh peserta karnaval 
songket SISCa 2016, sekaligus memberikan arti intrinsik dari Sawahlunto sebagai Kota Wisata Tambang Yang Berbudaya.

Event ini dinilai tidak hanya membantu promosi songket Silungkang tetapi juga menegaskan kembali kota Sawahlunto merupakan Kota Wisata Tambang, yang mana Kota Sawahlunto sempat berjaya sebagai kota batubara di era kolonial Belanda bahkan pernah menyandang sebutan kota industri batubara ternama di dunia.

Kota-kota lain di Sumatera Barat lebih banyak fokus dengan wisata pantai, atau pemandangan alam, tapi Sawahlunto memakai konsep yang berbeda karena dari awal kota ini sudah dikenal dengan sejarahnya sebagai kota tambang batubara. Kali ini, promosi pariwisata Sawahlunto juga dikemas secara unik melalui event tahunan yang baru dua kali diselenggarakan, yakni Sawahlunto International Songket Carnival (SISCa). Event ini tidak hanya memfokuskan pada promosi songket tetapi juga mempunyai tujuan untuk menegaskan Sawahlunto sebagai Kota Wisata Tambang Yang Berbudaya satu-satunya di Indonesia.

Songket Silungkang khas Provinsi Sumatera Barat tersebut hanya satu dari rangkaian produk kerajinan yang lahir dan berkembang di tengah kesahajaan masyarakat Indonesia. Selain itu, songket Silungkang telah menarik wisatawan mancanegara. Hasil karya kerajinan seperti songket ini adalah cerminan dari masyarakat di mana karya-karya tersebut dihasilkan.

Hasil karya yang masih dipertahankan tersebut menandakan bahwa masyarakat setempat masih menjungjung tinggi nilai-nilai budaya dan kesakralan yang diyakini tertuang dalam karya kerajinan tersebut. Sama halnya dengan hasil kreativitas songket pada event SISCa 2016 yang tidak terlepas dari kebudayaan Minang khususnya di Kota Sawahlunto. Sehingga, selain mengangkat konsep tambang, secara tidak langsung, event tersebut juga menjunjung tinggi nilai-nilai budaya setempat yang terangkum dalam visi kota Sawahlunto sebagai Kota Wisata Tambang Yang Berbudaya.

Teori konstruksi sosial atas realita berusaha melihat bagaimana fenomena keseharian mengkonstruksi realita sosial melalui sebuah kemampuan dalam memahami lingkungan sosial. Satu hal yang penting dalam gagasan Berger (dalam Bungin, 2008) tentang konstruksi sosial adalah bahwa nilai dan norma dikonstruksi secara objektif.

Asumsi dasar dari pemikiran konstruktivisme adalah: pertama, suatu kejadian (realitas) tidak hadir dengan sendirinya secara objektif, tetapi diketahui dan dipahami melalui pengalaman. Kedua, realitas dipahami melalui kategori-kategori bahasa secara situasional yang tumbuh dari interaksi sosial di dalam 
suatu kelompok sosial pada saat dan tempat tertentu. Ketiga, bagaimana suatu realitas dapat dipahami, ditentukan oleh konvensi-konvensi komunikasi yang dilakukan pada saat itu. Keempat, pemahaman terhadap realitas yang tersusun secara sosial membentuk banyak aspek penting lain dari kehidupan (Sendjaja, 1994: 325-326). Hal ini berarti ketika kita berpikir dan berperilaku dalam kehidupan sehari-hari, pada dasarnya merupakan persoalan tentang bagaimana kita memahami realitas yang kita hadapi.

Kegiatan karnaval songket yang dilakukan dalam rangka mempromosikan songket Silungkang memberikan makna intrinsik baik bagi penyelenggara maupun masyarakat, terutama para wisatawan yang menyaksikan karnaval tersebut. Fenomena yang terjadi tersebut, memberikan sebuah proses pengetahuan yang timbul dari realitas yang ada, bagaimana seorang individu memandang kegiatan ini sebagai kegiatan yang penting dalam city branding Sawahlunto Kota "Wisata Tambang Yang Berbudaya" melalui karnaval songket.

Proses tersebut dapat dipahami melalui penjelasan Berger dan Luckman (dalam Bungin, 2008: 15), yang mengatakan bahwa terjadi dialektika antara individu menciptakan masyarakat dan masyarakat menciptakan individu. Proses dialektika ini terjadi melalui eksternalisasi, objektivasi, dan internalisasi. Proses dialektis tersebut mempunyai tiga tahapan; Berger menyebutnya sebagai momen.

Dapat disimpulkan bahwa penjelasan Berger dan Luckman (dalam Bungin, 2008) tersebut menilai realitas tidak dibentuk secara ilmiah, tidak juga sesuatu yang diturunkan oleh Tuhan, tetapi sebaliknya, ia dibentuk dan dikonstruksi. Penyelenggara event SISCa 2016 dimulai dari interaksi antara pihakpihak yang terlibat dalam city branding kota Sawahlunto Sebagai Kota Wisata Tambang Yang Berbudaya melalui kerja sama berbagai pihak baik dari tataran pemerintahan, event organizer, komunitas, masyarakat luas ataupun pihak-pihak luar yang membantu city branding tersebut. Kegiatan ini dapat dikatakan sebagai bagian dari proses eksternalisasi.

Setelah dilakukannya interaksi melalui kerja sama yang terjadi antara pihak-pihak yang terlibat, menghasilkan sebuah pelaksanaan kegiatan karnaval songket dalam rangka city branding kota Sawahlunto. Bentukbentuk interaksi yang dilakukan dapat berupa pertemuan tatap muka dan kegiatan terkait city branding Kota Sawahlunto Sebagai Kota Wisata Tambang Yang Berbudaya melalui Sawahlunto International Songket Carnival (SISCa) 2016. Sehingga, dapat dikatakan bahwa hasil dari interaksi tersebut tergolong sebagai tahapan objektivasi. Seperti yang dijelaskan 
oleh Berger (dalam Bungin, 2008), sesudah tahap eksternalisasi ini terjadi, maka proses selanjutnya adalah memasuki tahap objektivasi.

Selanjutnya, pihak-pihak yang terkait ini tidak hanya memahami definisi kota Sawahlunto sebagai Kota Wisata Tambang Yang Berbudaya melalui Sawahlunto International Songket Carnival (SISCa) 2016 yang dialami bersama, namun tiap individu mendefinisikan kenyataankenyataan itu secara timbal balik. Seperti yang dikemukakan Evadianti (2017: 33), masyarakat merupakan pilar utama dalam pengembangan pariwisata, karena pada dasarnya pilar pariwisata itu terdiri dari pertama pemerintah, kedua swasta, ketiga masyarakat, yang sering disebut tiga pilar utama pariwisata. Kegiatan tersebut dapat dikatakan sebagai bagian dari proses internalisasi. Sehingga, teori konstruksi sosial atas realita ini dianggap relevan dalam membahas proses dialektika yang terjadi.

Branding merupakan kegiatan menciptakan sebuah brand yang dapat diidentifikasi, yang dapat membedakan produk atau jasa. Branding dikatakan berhasil apabila dapat membuat orang menerima nilai tambah yang sesuai dengan kebutuhan mereka.

Gambar atau simbol tidak hanya untuk merepresentasikan produk atau tempat. Namun lebih dari itu untuk memicu kesimpulan dan pengaruh sikap mengenai produk atau tempat tersebut. Seperti yang dipaparkan oleh
Duncan (2005: 71), branding adalah suatu proses penciptaan brand image yang mengajak konsumen untuk menggunakan hati dan pikiran mereka, membedakan produk yang sejenis satu dengan yang lainnya.

Sementara itu, branding yang dilakukan dalam menciptakan brand sebuah kota disebut dengan city branding. City branding adalah proses atau usaha membentuk merek dari suatu kota untuk mempermudah pemilik kota tersebut untuk memperkenalkan kotanya kepada target pasar (investor, tourist, talent, event) kota tersebut dengan menggunakan kalimat positioning, slogan, icon, eksibisi, dan berbagai media lainnya. Seperti penjelasan menurut Dinnie (2011: 3) bahwa:

"As cities compete globally to attract tourism, investment and talent, as well as to achieve many other objectives...(Sebagai sebuah kota harus bisa berkompetisi secara global untuk menarik wisatawan, investor dan talent, yang mana untuk mencapai beberapa tujuannya...)".

Beberapa tahun belakangan ini fokus perdebatan dari pemasaran tempat (city marketing) bergeser menjadi branding tempat (city branding) (Kavaratzis dalam Rahmat \& Salamah. 2014: 54). Kesadaran dan kepedulian masyarakat untuk membangun dan mempromosikan brand kota yang dimilikinya. Adapun istilah city branding yang dilakukan merupakan strategi brand pemerintah dan 
masyarakat kota tersebut.

Sebuah kotadengan brand yang kuat mampu menjadi berbeda di antara kota lainnya karena mampu mengarahkan preferensi dan pilihan yang dimiliki oleh pemangku kepentingan kota tersebut. Dengan menerapkan branding, sebuah kota mampu membangun identitas yang jelas, asosiasi yang kuat, dan menyelamatkan atribut positif agar mampu menempatkan diri dan memenangkan persaingan dengan kota lainnya. Seperti yang dijelaskan oleh Dinnie (2011: 5) bahwa:

"The key challenge for a city brand revolves around the issue of how to develop a strong 'umbrella' brand that is coherent across a range of different areas of activity with different target audiences, whilst at the same time enabling sector-specific brand comunications to be created."

"Tantangan utama bagi sebuah merek kota berkisar pada masalah bagaimana mengembangkan merek dengan 'payung' yang kuat yang koheren di berbagai bidang yang berbeda dari kegiatan branding dengan sasaran yang berbeda, sementara pada saat yang sama memungkinkan komunikasi brand pada sektor tertentu dibuat."

Proses branding tidak terlepas bagaimana cara mengkomunikasikan brand tersebut. City branding juga mencoba menerapkan komunikasi brand yang tepat agar mampu menciptakan diferensiasi dengan kotakota lainnya. Merek yang kuat berarti yang dibedakan dari pesaing untuk investasi, bisnis, pengunjung dan penduduk. Sehingga, kegiatan city branding dalam penelitian ini mencoba membentuk identitas kota Sawahlunto sebagai Kota Wisata Tambang Yang Berbudaya melalui sebuah event.

Berdasarkan pemaparan di atas, peneliti ingin melihat latar belakang dari pelaksanaan karnaval songket dan pemahaman penyelenggara dalam mengangkat event tersebut, sebagai salah satu bentuk kegiatan promosi dalam city branding kota Sawahlunto, serta bentuk tindakan-tindakan komunikasi dalam mempertahankan Sawahlunto Kota Wisata Tambang Yang Berbudaya melalui karnaval songket tersebut.

\section{METODE PENELITIAN}

Dalam merencanakan penelitian dibutuhkan cara pandang yang menjadi acuan peneliti selama upaya dalam mengungkap realitas yang ada di lapangan. Cara pandang yang dimaksud adalah paradigma yang dibutuhkan peneliti sebagai sudut pandang atau sejumlah asumsi yang dibangun dalam penelitian. Seperti yang diungkapkan oleh Bogdan dan Biklen (dalam Moleong 2007: 49), paradigma adalah kumpulan longgar dari sejumlah asumsi yang dipegang bersama, konsep atau proposisi yang mengarahkan cara berpikir dan penelitian.

Adapun paradigma dalam penelitian 
ini adalah paradigma konstruktivisme yang memandang ilmu sosial dengan analisis sistematis terhadap pengertian aksi sosial. Paradigma konstruktivisme yang digunakan pada penelitian ini dilandasi oleh cara peneliti mengungkap realitas yang dialami oleh pemerintah, penyelenggara event dan pihakpihak yang terlibat.

Penelitian ini bermaksud untuk mengungkap realitas dengan manganalisis kelompok yang tergabung dalam kegiatan city branding Sawahlunto melalui karnaval songket (pemerintah, penyelenggara event dan masyarakat lokal) secara alami. Dalam upaya mengungkap realitas dilapangan, penelitian ini menggunakan metode kualitatif. Metode kualitatif digunakan untuk menempatkan pandangan subjektif peneliti dalam memahami makna individu dari subjek yang diteliti. Selain itu, penggunaan metode kualitatif dalam penelitian ini juga untuk mengekplorasi informasi mengenai realitas yang ada di masyarakat melalui data dan fakta yang ada di lapangan.

Penelitian ini menggunakan jenis penelitian kualitatif, yang bertujuan untuk membahas fenomena yang terjadi pada sekelompok masyarakat lokal yang hidup dalam nilai dan norma. Nilai dan norma masyarakat Sawahlunto terdiri dari berbagai budaya, akibat kegiatan tambang zaman dahulu dimana orang-orang rantai berasal dari luar Sumatera Barat. Namun, nilai dan norma Minangkabau masih menjadi dominan.

Selanjutnya, masyarakat lokal bersama pemerintah telah mencoba membangun daerahnya dengan berbekal peninggalanpeninggalan sejarah tambang. Salah satu langkah dalam membangun kota Sawahlunto yang memiliki sejarah tambang adalah dengan mempromosikan kota wisata tambang melalui karnaval songket yang menjadi produk unggulan daerah tersebut.

Pengetahuan dan tujuan yang mereka miliki mempengaruhi perilaku mereka dalam mempromosikan daerah mereka dengan mencampurkan antara nilai dan norma dan sejarah tambang melalui sebuah karnaval songket. Keunikan yang terjadi tersebut menjadi sebuah pembahasan dengan jenis pendekatan studi kasus.

Studi kasus sangat bermanfaat ketika peneliti merasa perlu memahami suatu kasus spesifik, orang-orang tertentu, kelompok dengan karakteristik tertentu, ataupun situasi unik secara mendalam. Seperti yang dijelaskan oleh Yin (2011: 12), kekuatan yang unik dari studi kasus adalah kemampuannya untuk berhubungan sepenuhnya dengan berbagai jenis bukti (dokumen, peralatan, wawancara dan observasi). Studi kasus lebih dikehendaki untuk melacak peristiwa-peristiwa kontemporer, bila 
peristiwa-peristiwa yang bersangkutan tak dapat dimanipulasi.

Selanjutnya, pertimbangan penggunaan jenis penelitian studi kasus dalam penelitian ini, terlihat dari pertanyaan-pertanyaan yang diangkat peneliti. Dengan mengasumsikan bahwa pertanyaan-pertanyaan "mengapa" dan "bagaimana" tampaknya lebih cocok menggunakan jenis penelitian studi kasus ini. Untuk studi kasus, seperti yang dikemukakan oleh Yin (2011: 13), kelebihan tampak bilamana pertanyaan "bagaimana dan "mengapa" akan diarahkan keserangkaian peristiwakontemporer, di mana penelitinya hanya memiliki peluang yang kecil sekali atau tak mempunyai peluang sama sekali untuk melakukan kontrol terhadap peristiwa tersebut.

Teknik purposive sampling adalah teknik pengambilan sumber data dengan pertimbangan tertentu yang digunakan untuk menentukan key informant dalam penelitian ini. Berdasarkan kriteria informan yang telah ditentukan dalam penelitian ini, maka peneliti memilih (1) Dinas Perdagangan, Perindustrian, Koperasi dan Ketenagakerjaan Kota Sawahlunto; (2) Kepala Bidang Program dan Pengembangan Kepariwisataan Dinas Pariwisata dan Kebudayaan Kota Sawahlunto; (3) Kepala Dinas Pariwisata dan Kebudayaan Kota Sawahlunto; (4) Event Organizer PT. Cendekia Synergy; dan (5) Walikota Sawahlunto.
Pengumpulan data adalah teknik atau cara-cara yang dapat digunakan peneliti untuk mengumpulkan data di lapangan yang akan dikonstruksikan ke dalam hasil penelitian. Pada penelitian ini, peneliti menggunakan tiga teknik pengumpulan data, yaitu observasi, wawancara, dan dokumentasi. Untuk menganalisis data yang didapatkan di lapangan, peneliti menggunakan teknik analisis data Miles and Huberman yang lazim disebut interactive model.

\section{HASIL DAN PEMBAHASAN}

Faktor utama diselenggarakannya SISCa pada tahun 2015 yakni untuk memperluas pasar songket Silungkang yang mulai meredup. Hal tersebut juga tertuang dalam salah satu maksud dan tujuan SISCa tersebut yaitu untuk mengangkat kembali kejayaan songket Silungkang sebagai sebuah kekuatan ekonomi kreatif yang bersinergi dengan pariwisata kota Sawahlunto. SISCa juga merupakan salah satu bentuk promosi yang dilakukan dalam memperkuat Sawahlunto "Kota Wisata Tambang Yang Berbudaya”.

Sebagai wujud dari visi kota "Sawahlunto sebagai Kota Wisata Tambang Yang Berbudaya", dalam segi kepariwisataan terlihat dari bentuk-bentuk wisata yang dipugar dari peninggalan-peninggalan sejarah tambah, sedangkan dari segi kebudayaan juga terlihat sedikit banyaknya pengaruh sejarah tambang 
ke dalam konsep dan desain dari penampilan peserta dalam SISCa 2015 dan 2016. Terlebih lagi pada tahun 2016, keanekaragaman desain yang ditampilkan peserta banyak mengandung unsur wisata tambang kota Sawahlunto. Seperti yang tergambar dalam dokumentasi SISCa 2016 gambar 1.

Berdasarkan dokumentasi-dokumentasi pada gambar 1, dapat dikatakan bahwa representasi visi kota secara tidak langsung juga hadir dalam pertunjukan SISCa 2016. Bahkan, keterkaitan event SISCa 2016 dengan Sawahlunto Kota Wisata Tambang Yang Berbudaya secara jelas tertulis dalam visi dan misi event tersebut.

Selain itu, keterkaitan antara sejarah tambang dengan sejarah songket juga terealisasi dalam sebuah motif, seperti motif rantai. Selain itu, hasil modifikasi songket Silungkang juga menggambarkan beberapa bentuk wisata tambang kota Sawahlunto pada beberapa bentuk kreasi motif songket yang dibentuk pada dompet dan tas, seperti gambar 2 .

Berdasarkan gambar 2 dapat dikatakan bahwa produksi songket yang dihasilkan oleh pengrajin juga memiliki pengaruh yang kuat dalam mempromosikan kota Sawahlunto, khususnya pariwisata. Pada dasarnya, SISCa memang merupakan salah satu strategi promosi songket Silungkang, namun pengaruh yang besar tergambar dari bentuk event ini adalah event kota, sehingga menimbulkan bentuk yang sangat dominan dalam event pariwisata. Event menurut Hartono (2016) adalah kegiatan yang diselenggarakan untuk memperingati hal-hal penting sepanjang hidup manusia baik secara individu atau kelompok yang terkait dengan adat, budaya, tradisi dan agama yang

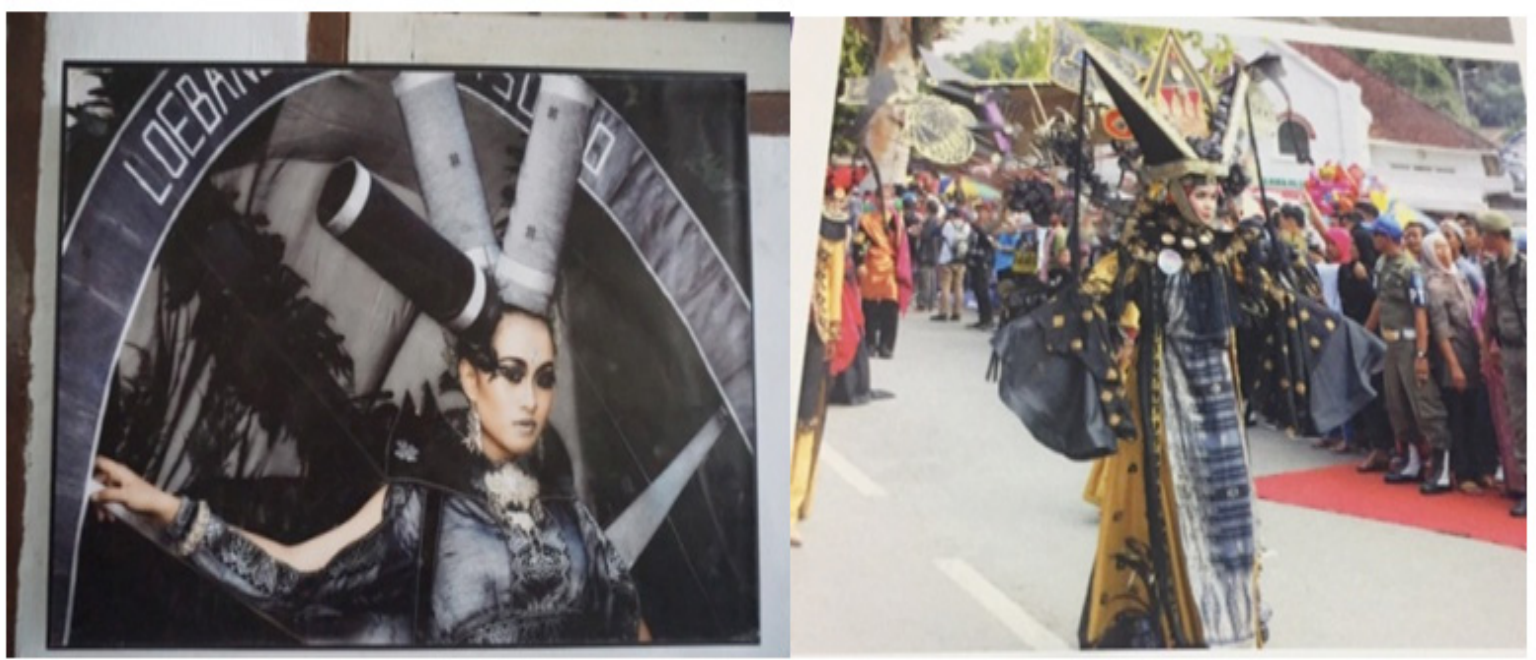

Sumber: Dokumentasi SISCa, 2016

Gambar 1 Bentuk Desain Wisata Tambang Kota Sawahlunto pada SISCa 2016 


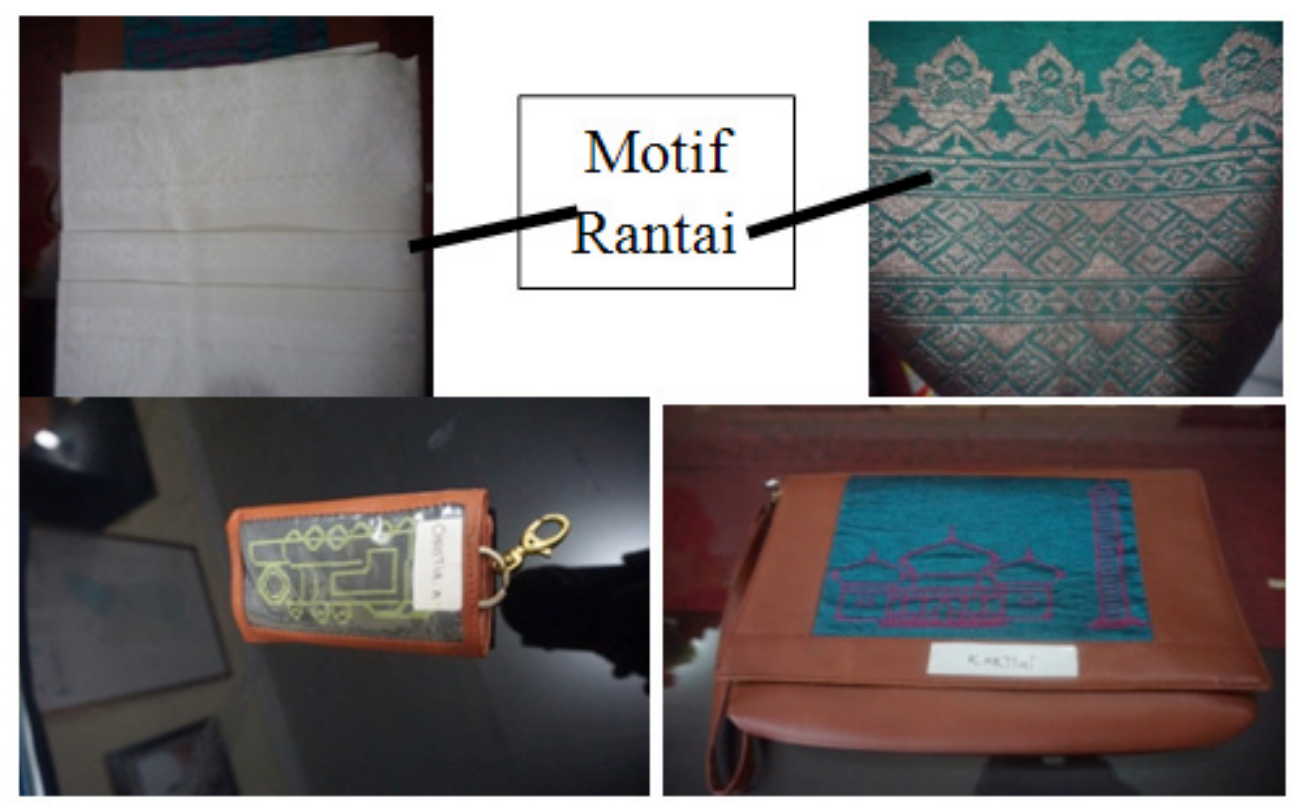

Sumber: Dokumentasi SISCa Disperindagkopnaker, 2016

Gambar 2 Hasil Modifikasi Songket pada SISCa 2016

diselenggarakan untuk tujuan tertentu serta melibatkan lingkungan masyarakat yang diselenggarakan pada waktu tertentu.

Berdasarkan hasil penelitian di lapangan, didapatkan bahwa tindakan komunikasi yang dilakukan oleh penyelenggara dalam city branding Sawahlunto Kota Wisata Tambang Yang Berbudaya melalui event SISCa 2016 terbagi dalam tiga tahapan event. Tahapan tersebut dimulai sebelum event ini dilakukan, mulai dari mengganti nama dari tahun 2014 ke 2015, menetapkan konsep yang akan diusung pada tahun 2015, dan perencanaan kembali untuk tahun 2016. Selanjutnya, pada tahapan event berlangsung dan terakhir tahapan setelah event.

Peneliti mencoba membagi dua proses konstruksi realita, yakni konstruksi sosial atas realita dari sejarah songket dan sejarah kota Sawahlunto dan konstruksi sosial atas realita event SISCa 2016 dan city branding Sawahlunto Kota Wisata Tambang Yang Berbudaya. Alasan peneliti membagi dua proses konstruksi sosial atas realitas dikarenakan sejarah yang sangat panjang sejak abad ke-16 dan abad ke-18, yang mana memiliki keterkaitan yang saling berhubungan antara sejarah songket dengan sejarah tambang, sehingga peneliti akan mengkaji konstruksi sosial atas realita dari sejarah songket dan sejarah kota Sawahlunto dengan asumsi dasar pemikiran konstruktivisme menurut Sendjaja (1994).

Pemahaman pada realitas bukan hadir dengan sendirinya, tetapi melalui sebuah 
pengalaman, interaksi dan konveksi komunikasi yang akan membentuk banyak aspek penting dari kehidupan masyarakat kota Sawahlunto tersebut. Konstruksi sosial atas realita event SISCa 2016 dan city branding Sawahlunto Kota Wisata Tambang Yang Berbudaya melalui pemikiran Momen Dialektika yang dilakukan penyelenggara pada SISCa 2016 dalam rangka city branding Sawahlunto Kota Wisata Tambang Yang Berbudaya terjadi dalam tiga tahapan tindakan komunikasi yaitu, tahap awal SISCa 2016, tahap berlangsungnya SISCa 2016 dan tahap pasca SISCa 2016.

Pertama, konstruksi sosial atas realita dari sejarah songket dan sejarah kota Sawahlunto seperti yang telah dijabarkan di atas, bahwa sejarah perjalanan tersebut memberikan pengalaman-pengalaman tertentu, yang kemudian tumbuh sebagai pemahaman masyarakat kota Sawahlunto melalui interaksi sosial yang terjadi. Sehingga, terlihat bahwa secara tidak langsung, masyarakat yang mengalami pengalaman-pengalaman yang dialaminya melalui sejarah songket dan sejarah kota tambang di Sawahlunto dikontruksi menjadi kehidupan masyarakat Sawahlunto yang memproduksi songket Silungkang dengan identitas kota tambang melalui interaksi sosial dan konvensi komunikasi sehari-hari. Hal tersebut terlihat dari bagaimana masyarakat memandang secara objektif sejarah tambang ke dalam motif songket Silungkang.

Secara sederhana, motif tambang tersebut bukan berarti membahas makna simbolik bagi masyarakat kota Sawahlunto. Tetapi proses dalam mengkonstruksi motif tambang pada songket Silungkang tersebut secara objektif dilakukan melalui pengalaman, interaksi dan konvensi komunikasi. Sehingga, persoalan dalam memahami lahirnya songket Silungkang di Sawahlunto tersebut dilalui dengan sejarah songket dan sejarah kota Sawahlunto itu sendiri.

Seperti halnya motif rantai tersebut tercipta dari 'orang rantai' pada sejarah tambang batu bara kota Sawahlunto. Dengan adanya sejarah tambang tersebut, melalui pengalaman, interaksi dan konvensi komunikasi, maka para penenun mencoba merealisasikan bentuk motif dari kegiatan tambang batu bara.

Selanjutnya, penerapan city branding pada SISCa 2016, yang mana kegiatan SISCa sendiri dilakukan dengan bersinergi antara pemerintah dan masyarakat lokal, seperti halnya konsep penerapan city branding baru-baru ini. Penyelenggara SISCa terdiri dari semua elemen pemerintahan, pihak ketiga dan masyarakat lokal baik penenun, pengusaha songket dan penyedia homestay. Dapat dikatakan kegiatan city branding Sawahlunto melalui SISCa 2016 dilakukan dengan kerjasama yang baik oleh pihak-pihak yang terlibat.

Selain itu, secara konsep juga tertuang dari 
visi dan misi diselenggarakannya SISCa, salah satunya menyangkut paradigma "Sawahlunto menjadiKotaWisataTambang Yang Berbudaya”. SISCa yang merupakan sebuah iconic event dinilai sebagai sebuah inovasi pemerintah kota yang mentransformasikan kota Sawahlunto dari kota tambang menjadi kota wisata tambang, dengan memadukan kekayaan budaya dan potensi lokal, yang menumbuhkan prakarsa kreatif dalam mendorong aspek ekonomi dan kepariwisataan. Dalam penyelenggaraan SISCa tersebut, dapat dikatakan bahwa kedua sektor ini saling bersinergi dan bergantung satu sama lainnya.

Penyelenggaraan event SISCa tersebut, dari sektor ekonomi merupakan sebuah usaha pengembangan industrikecilyang berfokus pada daya tarik tenun songket Silungkang. Sementara itu, penyelenggaraan SISCa, dari sektor pariwisata terlihat secara teknis menarik para pengunjung untuk datang ke kota Sawahlunto. Secara teknis pun, penyelenggara secara tidak langsung turut mengkomunikasikan Sawahlunto Kota Wisata Tambang Yang Berbudaya dengan cara merepresentasikan "wisata tambang" di Sawahlunto melalui "kreasi desain songket" pada event SISCa.

Ditinjau kembali pemahaman tentang city branding Sawahlunto Kota Wisata Tambang Yang Berbudaya melalui konsep branding menurut Duncan (2005: 71), bahwa proses penciptaan brand image yang mengajak konsumen untuk menggunakan hati dan pikiran mereka, membedakan produk yang sejenis satu dengan yang lainnya. Dalam hal ini, branding yang dilakukan dalam menciptakan brand sebuah kota (city branding) sehingga, proses penciptaan brand kota untuk mempermudah pemilik kota Sawahlunto (orang yang bernaung dalam kota tersebut) untuk memperkenalkan kotanya yang memiliki perbedaan dengan kotakota lain, khususnya di Sumatera Barat.

Kota Sawahlunto yang mempunyai wisata tambang satu-satunya di Sumatera Barat, menjadi keunikan tersendiri dalam menarik target pasar (investor, talent dan wisatawan). Seperti yang dijelaskan oleh Dinnie (2011: 3), sebagai sebuah kota harus bisa berkompetisi secara global untuk menarik wisatawan, investor dan talent, yang mana untuk mencapai beberapa tujuannya.

Adapun tujuan dari pemerintah kota Sawahlunto adalah mengkomunikasikan visi kota Sawahlunto sebagai Kota Wisata Tambang Yang Berbudaya pada tahun 2020 yang telah tertuang pada Peraturan Daerah Nomor 2 Tahun 2001. Dengan menerapkan branding, sebuah kota mampu membangun identitas yang jelas, asosiasi yang kuat, dan menyelamatkan atribut positif agar mampu menempatkan diri dan memenangkan persaingan dengan kota lainnya.

Seperti yang diungkapkan oleh Dinnie 
(2011: 5) bahwa tantangan utama bagi sebuah merek kota berkisar pada bagaimana mengembangkan merek dengan 'payung' yang kuat yang koheren di berbagai bidang yang berbeda dari kegiatan branding dengan sasaran yang berbeda, sementara pada saat yang sama memungkinkan komunikasi brand pada sektor tertentu dibuat. Hal tersebut terlihat dari upaya branding kota Sawahlunto melalui SISCa 2016.

Selain itu, pemahaman penyelenggara terkait city branding Sawahlunto Kota Wisata Tambang Yang Berbudaya melalui Sawahlunto International Songket Carnival (SISCa) 2016 juga terlihat dari kaitan antara visi dan misi SISCa 2016 dengan visi kota Sawahlunto. Dalam event SISCa 2016 terbentuk identitas kota Sawahlunto sebagai Kota Wisata Tambang Yang Berbudaya.

Berdasarkan hasil penelitian, Kota Wisata Tambang Yang Berbudaya belum ditetapkan sebagai brand kota Sawahlunto, hanya sebatas visi kota saja. Namun, kenyataan yang didapat, visi kota tersebut secara tidak langsung telah menjadi brand kota Sawahlunto karena telah menimbulkan arti tersendiri yang telah diasosiasikan sebagai bentuk identifikasi atau differensiasi dengan kota-kota lainnya seperti yang dipaparkan oleh American Marketing Association (AMA) dalam Rahmat \& Salamah (2014: 51).

Komunikasi pada SISCa 2016 juga menyampaikan brand kota Sawahlunto "Kota Wisata Tambang Yang Berbudaya”. Adapun tahapan tindakan komunikasi yang dilakukan penyelenggara dalam city branding Sawahlunto Kota Wisata Tambang Yang Berbudaya melalui SISCa 2016, sebagai berikut: (a) Komunikasi pada Tahap Awal SISCa 2016.

Berdasarkan hasil penelitian yang telah dijabarkan di atas, bahwa pada tahap awal SISCa 2016, komunikasi yang dilakukan pemerintah sebagai penyelenggara utama menjalin komunikasi dengan pihak internal (komunikasi dalam pemerintahan) dan dengan pihak eksternal (komunikasi dengan pihakpihak di luar pemerintahan). Komunikasi yang dilakukan dengan pihak internal tergambar sebagai bentuk komunikasi di dalam sebuah organisasi.

Komunikasi yang dijalankan di dalam pemerintahan kota Sawahlunto tidak jauh berbeda dengan komunikasi internal sebuah organisasi, yakni komunikasi atasan ke bawahan (vertikal up-to-down communication), komunikasi bawahan ke atasan (vertikal down-to-up communication) dan komunikasi sesama jabatan (horizontal communication). Komunikasi atasan ke bawahan (vertikal upto-down communication) disini adalah instruksi yang diberikan oleh Walikota kepada Kepala Disperindagkonaker untuk menangani acara SISCa 2016 sekaligus menurunkan SKPD 
kepada seluruh Dinas pemerintahan Kota Sawahlunto.

Selain itu, Walikota juga merealisasikan anggaran SISCa untuk tahun 2016. Sedangkan, komunikasi bawahan ke atasan berupa laporan dan usulan dari Kepala-kepala Dinas kepada Walikota saat rapat berlangsung. Kemudian, koordinasi di antara kepala Dinas ataupun sesama panitia penyelenggara disebut dengan komunikasi sesama jabatan (horizontal communication).

Sementara itu, komunikasi pemerintah dengan pihak eksternal dimulai oleh Walikota Sawahlunto yang mengadakan pertemuan dengan Menteri Perdagangan. Perencanaan SISCa 2016 sebagai event promosi songket Silungkang disetujui oleh Menteri Perdagangan sebagai hasil dari komunikasi yang dilakukan. Selanjutnya, Walikota mengadakan pertemuan dengan pihak ketiga, EO dari Jakarta, untuk membicarakan konsep SISCa 2016 sekaligus dalam rangka melakukan city branding Sawahlunto melalui event tersebut.

Komunikasi eksternal lainnya juga dilakukan kepada para penenun, pengusaha songket, masyarakat dan para calon peserta karnaval songket. Proses komunikasi yang dilakukan kepada pihak-pihak eksternal tersebut dilakukan oleh pihak pemerintah yang tergabung dalam kepanitian sesuai dengan tanggung jawab yang telah ditentukan. Pihak- pihak eksternal tersebut sangatlah penting dalam menunjang kesuksesan acara SISCa 2016.

Interaksi yang dilakukan pada proses komunikasi tahap awal SISCa 2016 antara pemerintah dengan pihak eksternal dimaknai sebagai bentuk usaha penyampaian maksud pemerintah untuk mengadakan event SISCa dalam rangka transformasi visi Kota Sawahlunto. Sebagaimana yang telah dikemukakan Berger dan Luckman dalam Bungin (2008: 15) bahwa usaha pencurahan individu kepada masyarakat yang bersifat objektif disebut sebagai eksternalisasi.

Sebagai kenyataan objektif, masyarakat berada di luar diri manusia. Sehingga, jika dikaitkan dengan hasil penelitian, tahapan eksternalisasi yang terjadi adalah pemerintah dikategorikan sebagai subjek tunggal yang mencoba untuk mencurahkan maksud dan tujuan diadakannya event SISCa dalam rangka city branding Sawahlunto "Kota Wisata Tambang Yang Berbudaya” kepada pihak-pihak eksternal yang dikategorikan sebagai sekumpulan masyarakat. Komunikasi yang dilakukan antara pemerintah dengan pihak eksternal tersebut dapat dikatakan sebagai eksternalisasi menurut Berger dan Luckman (dalam Bungin, 2008).

Kemudian hasil komunikasi yang dilakukan antara pemerintah dengan pihak eksternal tersebut berupa kesepakatan untuk mendukung event kota Sawahlunto. Pemahaman terkait 
kegiatan city branding Sawahlunto melalui SISCa 2016 tergambar melalui pemahaman pihak eksternal tentang visi kota Sawahlunto sehingga terjadi sebuah proses institusionalisasi.

Maksud peneliti dengan proses institusionalisasi disini adalah peneliti melihat bahwa berdasarkan hasil penelitian, pemerintah seakan-akan memasukkan dirinya ke masyarakat melalui visi kota yang ditransformasikan melalui event SISCa 2016. Sekaligus untuk mempromosikan songket Silungkang sebagai upaya peningkatan perekonomian masyarakat sehingga masyarakat merasakan maksud dari pemerintah tersebut.

Hasil dari penyampaian maksud melalui interaksi yang dilakukan pemerintah dengan pihak-pihak eksternal, berupa pemahaman itulah dapat dikatakan sebagai tahapan objektivasi menurut Berger dan Luckman (dalam Bungin, 2008). Tindakan komunikasi yang terjadi pada tahap awal SISCa 2016 dalam rangka city branding Sawahlunto yang ternyata sesuai dengan bentuk tahapan eksternalisasi dan objektivasi menurut Berger dan Luckman (dalam Bungin, 2008); Komunikasi yang terjadi pada saat berlangsungnya SISCa 2016 terdiri dari komunikasi verbal dan komunikasi non verbal.

Komunikasi verbal terjadi saat pertemuan tatap muka saat acara berlangsung. Selain itu, koordinasi di antara panitia juga merupakan komunikasi verbal. Meninjau komunikasi verbal yang terjadi saat acara berlangsung, yakni antara pihak penyelenggara SISCa 2016 dengan semua para undangan, masyarakat, wisatawan dan peserta terjadi secara langsung.

Proses komunikasi yang terjadi merepresentasikan bahwa semua para undangan, masyarakat, wisatawan dan peserta yang dianggap sebagai pihak eksternal pemerintahan atau yang disebut sebagai sebuah masyarakat memahami definisi dari event SISCa 2016. Dapat dikatakan bahwa setelah melewati tahapan eksternalisasi dan objektivasi, masyarakat (pihak-pihak eksternal) seakan-akan juga merupakan bagian dalam pemerintahan dengan mendukung suksesnya event tersebut. Proses penarikan kembali tentang pemahaman event SISCa 2016 dari masyarakat di luar pemerintahan ini dapat disebut sebagai tahapan internalisasi menurut tahapan momen dialektika Berger dan Luckman (dalam Bungin, 2008).

Selanjutnya, komunikasi non verbal mencerminkan sebuah pemaknaan simbolik secara langsung melalui kemasan event SISCa 2016, seperti penampilan peserta karnaval songket, pameran hasil kerajinan masyarakat Sawahlunto dan penyediaan jasa homestay yang berbudaya, sebagai representasi dari Sawahlunto "Kota Wisata Tambang Yang Berbudaya". Sehingga, secara tidak langsung 
telah menjadi brand identity kota Sawahlunto.

Tindakan Komunikasi pada tahap pasca SISCa 2016 dilakukan dengan berbagai pihak yang telah dilakukan pada tahap awal dan saat berlangsungnya SISCa 2016, guna menjalin hubungan baik untuk kedepannya. Salah satunya, pemerintah juga tetap menjalin hubungan yang baik dengan tetap menjaga komunikasi dengan pihak EO, media, masyarakat, penenun dan pengusaha songket. Pemerintah menjalin komunikasi dengan pihak media sebagai sarana pendukung dalam mem-branding kota Sawahlunto melalui pemberitaan SISCa 2016 dengan menampilkan foto-foto ataupun iconicon Sawahlunto yang mencerminkan wisata tambang yang ada.

\section{SIMPULAN}

Berdasarkan tahapan yang telah peneliti lakukan mulai dari pengumpulan sampai pada pengolahan data, maka dapat ditarik kesimpulan bahwa alasan penyelenggara menjadikan Sawahlunto International Songket Carnival (SISCa) 2016 dalam city branding Sawahlunto Kota Wisata Tambang Yang Berbudaya adalah songket Silungkang merupakan produk unggulan masyarakat Sawahlunto yang berbasis budaya kota Sawahlunto. Cerminan budaya yang terdapat pada songket Silungkang dapat menjadi transformasi sejarah songket dan sejarah tambang kota Sawahlunto. Dengan demikian, event SISCa 2016 merupakan representasi city branding Sawahlunto Kota Wisata Tambang Yang Berbudaya.

Pemahaman penyelenggara terkait city branding Sawahlunto Kota Wisata Tambang Yang Berbudaya melalui Sawahlunto International Songket Carnival (SISCa) 2016 adalah dalam SISCa 2016 penyelenggara dapat merepresentasikan Kota Wisata Tambang Yang Berbudaya melalui bentuk kemasan event tersebut. Selain memberikan dampak ekonomi (peningkatan omset dan perluasan pasar songket Silungkang), juga memberikan dampak pariwisata sehingga secara tidak langsung city branding Sawahlunto terealisasikan melalui SISCa 2016.

Tindakan komunikasi yang dilakukan oleh penyelenggara dalam city branding Sawahlunto Kota Wisata Tambang Yang Berbudaya melalui Sawahlunto International Songket Carnival (SISCa) 2016, terdiri dari tiga tahapan, yakni tahap awal SISCa 2016, tahap berlangsungnya SISCa 2016 dan tahap pasca SISCa 2016. Dari pemahaman dan tindakan komunikasi yang dilakukan penyelenggara SISCa 2016 sudah dapat dikatakan efektif dalam rangka city branding Sawahlunto, namun perlu ditingkatkan kali pada acara SISCa selanjutnya agar pengkomunikasian brand Sawahlunto dapat direpresentasikan maksimal melalui SISCa tersebut. 
DAFTAR PUSTAKA

Bungin, B. (2007). Penelitian kualitatif: komunikasi, ekonomi, kebijakan publik, dan ilmu sosial lainnya. Jakarta: Kencana Prenada Media Group.

(2008). Sosiologi komunikasi (teori, paradigma dan discourse teknologi komunikasi di masyarakat. Jakarta: Kencana Prenada Media Group.

Dinnie, K. (2011). City branding: Theory and Cases. London: Palgrave Macmillan.

Duncan, T. (2002). Imc: using advertising \& promotion to build brands. New York: McGraw Hill.

(2005). Principle of advertising and imc, international. Second edition. New York: McGrawHill.

Evadianti, Y. (2017). Reposisi brand dalam festival krakatau oleh dinas kebudayaan dan pariwisata provinsi lampung. PRofesi Humas: Jurnal Ilmiah Ilmu Hubungan Masyarakat, Volume 2, No. 1, Agustus 2017, hlm. 23-36. DOI: 10.24198/prh. v2i1.10610.

Hartono, N. A. (2016). Pelaksanaan kegiatan special event jakarta goes pink oleh lovepink indonesia. Jurnal Komunikasi. Vol. X, No 2, 159-170.

Moleong, L. J. (2007). Metodologi penelitian kualitatif. Edisi Revisi. Bandung: Remaja Rosdakarya.

Rahmat, M. Y. \& Salamah, U. (2014). Branding tempat: membangun kota, kabupaten, dan provinsi berbasis identitas. Jakarta: Makna Informasi.

Sendjaja, S. D. (1994). Pengantar komunikasi. Jakarta: Universitas Terbuka.

Yin, R. K. (2011). Studi kasus: desain dan metode. Jakarta: Raja Grafindo Persada. 